Int. J. Electrochem. Sci., 15 (2020) $4072-4088$

\title{
Dielectric and Optical properties of $\mathrm{RE}_{1.8} \mathrm{Sr}_{0.2} \mathrm{CuO}_{4 \pm \delta}(\mathrm{RE}=\mathrm{La}$, Pr, Nd)
}

\author{
Basma Marzougui ${ }^{1,2}$, Mohamed Ikbal Houchati ${ }^{1}$, Youssef Ben Smida ${ }^{1,}$, , Naser Sdiri ${ }^{3}$, \\ Riadh Marzouki ${ }^{4,5}$, Ahmed Hicham Hamzaoui ${ }^{1}$ \\ ${ }^{1}$ Université de Carthage, Centre National des Recherches en Sciences des Matériaux, Laboratoire de \\ Valorisation des Matériaux Utiles, Technopôle Borj Cedria, B.P. 73, 8027 Soliman, Tunisie \\ ${ }^{2}$ Université de Carthage, Faculté des sciences de Bizerte, Jarzouna - Bizerte - 7021, Tunisie. \\ ${ }^{3}$ Université de Carthage, Centre National de Recherches en Sciences des Matériaux, Laboratoire de \\ Physicochimie de Matériaux et leurs Applications, Technopôle Borj Cedria, BP 73, 8027 Soliman, \\ Tunisie. \\ ${ }^{4}$ Department of Chemistry, College of Science, King Khalid University, Abha 61413, Saudi Arabia. \\ ${ }^{5}$ Department of Chemistry, Faculty of Sciences of Sfax, University of Sfax, 3038, Tunisia \\ *E-mail : youssef_smida@yahoo.fr
}

doi: $10.20964 / 2020.05 .42$

Received: 9 December 2019 / Accepted: 30 January 2020 / Published: 10 April 2020

The present work investigates the optical and dielectric properties of three Sr-doped rare earth copper oxide $\mathrm{RE}_{1.8} \mathrm{Sr}_{0.2} \mathrm{CuO}_{4 \pm \delta}(\mathrm{RE}=\mathrm{La}, \mathrm{Nd}, \mathrm{Pr})$ synthesized by the solid-state reaction at $1000{ }^{\circ} \mathrm{C}$. The title samples were characterized by X-ray powder diffraction which shows that the three samples crystallize in the tetragonal system with close unite cell parameters. The morphology and the practical size of the powder were studied by the means of Scanning Electron Microscopy and the grain size are about 1-5 $\mu \mathrm{m}$. The optical band gap of the titled compounds have been determined and they are in the 1.19-1.30 eV range. Detailed studies of dielectric properties of the compounds as a function of frequencies at different temperatures $\left(270-500^{\circ} \mathrm{C}\right)$ show that $\mathrm{La}_{1.8} \mathrm{Sr}_{0.2} \mathrm{CuO}_{4 \pm \delta}$ and $\operatorname{Pr}_{1.8} \mathrm{Sr}_{0.2} \mathrm{CuO}_{4 \pm \delta}$ have a very high dielectric constant $\varepsilon^{\prime}>10^{9}$ compared to $\mathrm{Nd}_{1.8} \mathrm{Sr}_{0.2} \mathrm{CuO}_{4 \pm \delta}\left(\varepsilon^{\prime} \approx 800\right)$. While $\mathrm{La}_{1.8} \mathrm{Sr}_{0.2} \mathrm{CuO}_{4 \pm \delta}$ and $\operatorname{Pr}_{1.8} \mathrm{Sr}_{0.2} \mathrm{CuO}_{4 \pm \delta}$ have an important dielectric loss $(\approx 65-70)$ compared to $\mathrm{Nd}_{1.8} \mathrm{Sr}_{0.2} \mathrm{CuO}_{4 \pm \delta}$ which has a very low value $(\approx$ $0.65)$.

Keywords: Cuprate, Rare Earth, optical bond gap, dielectric properties.

\section{$\underline{\text { FULL TEXT }}$}

(C) 2020 The Authors. Published by ESG (www.electrochemsci.org). This article is an open access article distributed under the terms and conditions of the Creative Commons Attribution license (http://creativecommons.org/licenses/by/4.0/). 